\title{
Effects of chromium yeast supplementation on postprandial glycaemic and insulinaemic responses in insulin-resistant ponies and horses
}

\author{
Ingrid Vervuert', Barbara Oßwald',2, Derek Cuddeford ${ }^{3}$ und Manfred Coenen ${ }^{1}$ \\ Institut für Tierernährung, Ernährungsschäden und Diätetik, Veterinärmedizinische Fakultät, Universität Leipzig ${ }^{1}$, Pferdeklinik an der Rennbahn, Iffezheim² und \\ Royal (Dick) School of Veterinary Studies, University of Edinburgh ${ }^{3}$
}

\begin{abstract}
Summary
The trace element chromium $(\mathrm{Cr}$ ) has attracted attention because $\mathrm{Cr}$ supplements have been shown to benefit biological functionality and health in both humans and animals. It has been suggested that $\mathrm{Cr}$ decreases insulin levels and improves glucose disposal in type 2 diabetic and obese humans. Therefore, the aim of the study was to examine the effect of feeding Cr-enriched yeast on glucose metabolism in insulin-resistant ponies and horses. 27 insulin-resistant ponies and horses, mean age $( \pm S D) 13.9( \pm 4.8)$ years, mean body mass $( \pm$ SD) $422( \pm 138) \mathrm{kg}$, mean body condition score $( \pm S D) 7.6( \pm 0.8)$ on a scale of $1-9$, were used in a placebo-controlled study. The ponies and horses were fed for four weeks either a yeast product without $\mathrm{Cr}$ (= placebo, $\mathrm{N}=12$ ), or a $\mathrm{Cr}$-enriched yeast (= verum, $2 \mathrm{~g}$ organic $\mathrm{Cr} 3+/ \mathrm{kg}$ yeast, $25 \mu \mathrm{g} / \mathrm{kg} \mathrm{BW,} \mathrm{N}=15)$. During experimental period all animals were on a hay-based diet (1.2 kg hay/100 kg BW). A starch tolerance test (STT, $1.5 \mathrm{~g}$ starch/kg BW) was performed at the beginning and at the end of the study. Blood was collected following a standardized protocol. Plasma glucose concentrations were determined by glucose oxidase assay and plasma insulin was determined by radioimmunoassay. The STT revealed exaggerated glucose and insulin responses, reflecting an impaired glucose tolerance in all animals. Postprandial insulin responses were significant higher at the beginning of the study in the group to be fed verum when compared to the placebo group. After supplementation, plasma insulin responses were significantly modified by $\mathrm{Cr}$ intake (diet $\mathrm{p}<0.05$ ), suggesting an improved glucose regulation. Plasma glucose responses were not affected by the different treatments. Cr supplementation for four weeks improved glucose metabolism in ponies and horses suggesting that $\mathrm{Cr}$ facilitated insulin signaling. However, it must be emphasized that the ponies and horses still had impaired glucose regulation as indicated by supraphysiological glucose and insulin responses to the STT when compared to healthy horses.
\end{abstract}

Keywords: glucose, insulin, insulin resistance, chromium yeast, supplementation, ponies, horses

Effekte der Chromhefezulage auf die postprandialen Veränderungen von Glucose und Insulin im Blut bei insulin-resistenten Ponys und Pferden

Chrom besitzt eine besondere Bedeutung in der Therapie der Insulinresistenz beim Menschen, da Chrom die Bindung von Insulin am Rezeptor aktivieren kann. Ziel dieser Studie war es, die Supplementierung von Chrom auf die postprandiale Glucosehomöostase bei insulin-resistenten Pferden bzw. Ponys zu überprüfen. Für die Placebo kontrollierte Studie standen 27 insulin-resistente Ponys bzw. Pferde (Alter 13,9 \pm 4,8 Jahre, mittlerer Body Condition Score 7,6 0,8 auf einer Skala von 1-9) zur Verfügung. 12 Tiere erhielten entweder ein Placebo (Placebo $=$ Hefe ohne Chrom) oder 15 Ponys bzw. Pferde wurden mit einer chromhaltigen Hefe (= Verum, $2 \mathrm{~g}$ organisches $\mathrm{Cr} 3+/ \mathrm{kg} \mathrm{Hefe}$, $25 \mu \mathrm{g} \mathrm{Cr} / \mathrm{kg} \mathrm{KM}$ ) über einen Zeitraum von 4 Wochen supplementiert. Während der Versuchsperiode wurden die Ponys bzw. Pferde ausschließlich mit Heu gefüttert (1,2 kg/100 kg KM). Zu Beginn und am Ende der Supplementierungsphase wurde ein Stärketoleranztest (STT 1 und STT 2; 1,5 g Stärke/kg KM) durchgeführt und nach einem standardisierten Protokoll Blutproben zur Glucose- und Insulinbestimmung entnommen. Plasma Glucose wurde enzymatisch mittels Oxidase Assay and Plasma Insulin wurde mittels Radioimmunoassay bestimmt. Alle Ponys bzw. Pferde reagierten mit abnorm hohen Glucose- und Insulinkonzentrationen im Verlaufe der STT 1 und STT 2. Auffällig war, dass die Tiere der Verumgruppe vor Beginn der Supplementierungsperiode signifikant höhere Insulinwerte im Vergleich zur korrespondierenden Placebogruppe aufwiesen. Nach der vierwöchigen Supplementierungsphase konnte bei den Tieren, die $\mathrm{Cr}$ erhielten, eine deutliche Reduktion bei der Insulinreaktion im Verlaufe des STT 2 beobachtet werden, wohingegen die Placebopferde nur eine moderate Veränderung in der Insulinreaktion aufwiesen. Ein Effekt der Cr Supplementierung auf die Plasma Glucosekonzentrationen konnte im Verlauf der Studie nicht beobachtet werden. Cr scheint auch bei Ponys bzw. Pferden zu einer Verbesserung der Insulinresistenz zu führen, allerdings muss betont werden, dass die Ponys bzw. Pferde auch weiterhin nach der vierwöchigen Cr-Supplementierungsphase abnorm hohe Insulinreaktionen aufwiesen.

Schlüsselwörter: Glucose, Insulin, Insulinresistenz, Chromhefe, Supplementierung, Ponys, Pferde

\section{Introduction}

Insulin resistance $(\mathrm{IR})$ is associated with impaired insulin activity and a compensatory increase in insulin secretion (Johnson 2002). The molecular aetiology of IR include defects of insulin signalling, such as reduced insulin receptor tyrosine kinase activity, and reduced post-receptor phosphorylation steps (Kas- hyap and DeFronzo 2007). As a consequence, glucose transport and glucose metabolism such as, glucose phosphorylation, glycogen synthesis or glucose oxidation, is impaired in different tissues. In humans, IR and associated hyperinsulinaemia contribute to the metabolic syndrome that typically includes impaired glucose tolerance or type 2 diabetes, obesity, dyslipidaemia, raised blood pressure and coronary artery dise- 
ase (Reaven 1998, Potenza and Mechanik 2009). Currently, the Equine Metabolic Syndrome (EMS) has been defined as a syndrome of insulin resistance; regional or general adiposity; and clinical or subclinical laminitis (ACVIM Consensus Statement 2009). In this context, it is supposed that IR and hyperinsulinaemia alter vascular dynamics and endothelial function (Asplin et al. 2007), and obesity creates a proinflammatory state in horses and ponies (Vick et al. 2008).

Although epidemiological data are lacking, it seemed that ponies and light horses, like Quarter horses, are more susceptible to EMS than Thoroughbred or Standardbred horses (Freestone et al. 1992, ACVIM Consensus Statement 2009). In the horse, dietary interventions aimed at reducing obesity, include energy restriction, mainly by reducing sugar and starch intake (van Weyenberg et al. 2008, Carter et al. 2009) and should be accompanied by physical activity. In humans, complementary dietary recommendation involve specific supplements such as soluble dietary fibre (e.g. pectins), omega 3 fatty acids (fish, flaxseed oil), sources of polyphenols and isoflavones (e.g. red wine, soy protein), herbs (e.g. cinnamon extract, green tea), and certain major minerals and trace elements (e.g. magnesium, zinc, chromium; Potenza and Mechanick 2009). In horses, data about complementary dietary strategies in the treatment of EMS are lacking. In humans, chromium $(\mathrm{Cr})$ has been the most studied, and some reports have suggested that $\mathrm{Cr}$ supplementation may increase insulin sensitivity and improve glucose tolerance, although the findings were equivocal (Bartlett and Eperjesi 2008, Potenza and Mechanik 2009).

$\mathrm{Cr}$ is an essential trace element that is involved in the metabolism of carbohydrates, lipids and proteins by amplifying the activity of insulin (Mertz 1993). In diabetic humans and rats, Cr supplementation has been shown to increase the cellular uptake of glucose and stimulate insulin metabolism (Lukaski 1999, Cefalu et al. 2002).

$\mathrm{Cr}$ is present in several oxidation states, but is most stable in the trivalent state, the predominant form in biological systems (McDowell 2003). However, the $\mathrm{Cr}$ content of foods has not been clearly defined and inorganic $\mathrm{Cr}^{+}$is poorly absorbed (Table 1). In contrast, $\mathrm{Cr}^{6+}$ that is derived mainly from industrial exposure is absorbed more readily (McDowell 2003). The daily dietary $\mathrm{Cr}$ intake by humans is generally low whereas in animals, it is considered to be adequate to meet physiological need. There is little retention of $\mathrm{Cr}$ and that which is absorbed is excreted primarily via the kidneys (McDowell 2003). In general, marginal $\mathrm{Cr}$ intakes can be compensated by $\mathrm{Cr}$-containing supplements that contain inorganic $\mathrm{CrCl}_{3}$ or the more available organic forms such as $\mathrm{Cr}$-yeast, $\mathrm{Cr}$ methionine, $\mathrm{Cr}$ nicotinate ( $\mathrm{CrNic}), \mathrm{Cr}$ tripicolinate (CrTri) and $\mathrm{Cr}$ picolinate ( $\mathrm{CrPic}$ ).

Equivocal results were obtained with horses following $\mathrm{Cr}$ supplementation. Pagan et al. (1995) measured lowered blood levels of glucose, insulin and cortisol during exercise in healthy Thoroughbred horses. A trend for a lower insulin response was measured in healthy mares subjected to an intravenous glucose tolerance test (Gentry et al. 1999). Ott and Kivipelto (1999) fed $\mathrm{Cr}$ to yearling horses and showed an increased glucose clearance in the supplemented group.
Unlike these results, Vervuert et al. (2006) found higher plasma glucose levels during exercise in $\mathrm{Cr}$-supplemented healthy horses. Cartmill et al. (2005) found that dietary Cr supplementation had no effect on glucose dynamics or insulin sensitivity in mature horses with high body condition scores and hyperleptinaemia.

As $\mathrm{Cr}$ has been proposed as a complementary therapy in the treatment of IR in horses under practical feeding conditions, the aim of the current study was to examine the effect of feeding $\mathrm{Cr}$-enriched yeast on glucose metabolism in insulin-resistant ponies and horses.

\section{Material and methods}

In a preliminary trial, a total of 83 ponies and horses were checked for the following criteria: obesity (Henneke et al. 1983), history of laminitis and impaired glucose tolerance. Glucose tolerance was assessed by a modified starch tolerance test. The test meal (1.5 g starch $/ \mathrm{kg} \mathrm{BW})$ was fed at $0730 \mathrm{~h}$ following a $12 \mathrm{~h}$ overnight fast. Blood samples for plasma glucose and insulin were collected 30 min before feeding the test meal, and thereafter at 60 min intervals for $3 \mathrm{~h}$. Postprandial glycaemic and insulinaemic responses were compared to plasma glucose and insulin profiles of healthy ponies and horses. Those ponies and horses which implement all three criteria were included in the study.

\section{Animals and diets}

27 insulin-resistant ponies or horses, mean age ( \pm SD) 13.9 $( \pm 4.8)$ years, mean body mass $( \pm S D) 422( \pm 138) \mathrm{kg}$, mean body condition score (BCS) $( \pm S D) 7.6( \pm 0.8)$ (Henneke et al. 1983) were used in a placebo-controlled study. The animals were individually housed in box stalls and bedded on wood shavings. Ponies and horses had free access to a paddock 8$12 \mathrm{~h}$ daily. Additionally, animals were walked daily for 30-60 min. During the experimental period (4 weeks) all animals were on a hay-based diet (1.2 kg hay/100 kg BW).

This project was approved by the ethics committee on animal welfare of Baden-Württemberg in accordance with German legislation on animal rights and welfare.

\section{Supplementation}

The ponies and horses were fed for four weeks either a yeast product without $\mathrm{Cr}$ (= placebo, $\mathrm{N}=12$, table 2$)$, or a $\mathrm{Cr}$ enriched yeast (= verum, $2 \mathrm{~g}$ organic $\mathrm{Cr} 3+/ \mathrm{kg}$ yeast, 25 $\mu \mathrm{g} / \mathrm{kg} \mathrm{BW}, \mathrm{N}=15$, table 3). The placebo or the Cr-enriched yeast was blended into a commercial, fiber-enriched compound feed. The supplement was given once a day in the morning. The allocation to the respective group was executed by rotation.

\section{Starch tolerance test}

A starch tolerance test (STT, $1.5 \mathrm{~g}$ starch/kg BW) was performed at the beginning (STT 1) and at the end (STT 2) of the 
Table 1 The biology of Cr (Mordeni et al. 1997, McDowell 2003, Anke et al. 2005)

Beschreibung des Chroms im Stoffwechsel (Mordeni et al. 1997, McDowell 2003, Anke et al. 2005)

\begin{tabular}{|c|c|c|}
\hline & Cereals: & $0.1-20$ \\
\hline & Kernels: & oat 0.49 , barley 0.35 , wheat 0.64 , rye 0.6 \\
\hline & Meat: & 0.15 \\
\hline \multirow{6}{*}{ Feedstuffs $(\mathrm{mg} / \mathrm{kg})$ : } & Milk: & 0.015 \\
\hline & Egg: & $0.005-0.02$ (egg yolk > 20 times) \\
\hline & Hay: 0. & \\
\hline & Water: 0. & 100 \\
\hline & Minerals: & $60-500$ \\
\hline & $\mathrm{Cr}^{3+}:$ & most stable oxidation state, predominant form in biological systems \\
\hline \multirow[t]{3}{*}{ Specification: } & $\mathrm{Cr}^{6+}:$ & bound to oxygen, strongly oxidizing, toxic properties \\
\hline & $\mathrm{Cr}^{0}, \mathrm{Cr}^{2+}:$ & no relevance \\
\hline & $\begin{array}{l}\text { Passive ab } \\
\text { transferrin }\end{array}$ & ion (small intestine), presumably active transport mechanism, transport of $\mathrm{Cr}$ in blood via \\
\hline \multirow[t]{2}{*}{ Absorption: } & Inorganic & $<0.5-2 \%$ (e.g. $\left.\mathrm{CrCl}_{3}\right)$ \\
\hline & Organic C & 25 - 30 \% (e.g. high Cr-yeast, CrNic, CrPic) \\
\hline \multirow[t]{3}{*}{ Excretion: } & After abso & : mainly via urinary tract with small losses in faeces, sweat and hair \\
\hline & Liver: & $0.04-1$ \\
\hline & Kidney: & $0.05-6.2$ \\
\hline \multirow[t]{3}{*}{ Storage $(\mathrm{mg} / \mathrm{kg})$ : } & Spleen: & $0.05-0.3$ \\
\hline & Hair: & $0.20-3.3$ \\
\hline & Muscle: & $0.10-0.2$ \\
\hline \multirow{2}{*}{ Requirements: } & Humans: & $50.0-200 \mu \mathrm{g} / \mathrm{day}$ \\
\hline & Horses: & no available information \\
\hline \multirow{3}{*}{ Deficiency: } & \multirow{2}{*}{\multicolumn{2}{|c|}{$\begin{array}{l}\text { Decreased sensitivity of peripheral tissues to insulin } \\
\text { Impaired protein metabolism }\end{array}$}} \\
\hline & & \\
\hline & $\mathrm{Cr}^{3+}:$ & very low toxicity \\
\hline Toxicity: & $\mathrm{Cr}^{6+}:$ & allergic dermatitis, skin ulcers, bronchogenic carcinoma by industrial exposure to $\mathrm{Cr}$ \\
\hline
\end{tabular}

Table 2 Plasma glucose (mmol/L) and plasma insulin $(\mu \mathrm{U} / \mathrm{mL})$ concentrations before and after experimental period for the placebo and $\mathrm{Cr}$ group Plasma Glucose ( $\mathrm{mmol} / \mathrm{l})$ und Plasma Insulin $(\mu \mathrm{U} / \mathrm{ml})$ im Verlaufe der Beobachtungsperiode für die Placebo- oder Chromgabe

\begin{tabular}{lccc}
\hline Breed & Age & BCS & N \\
\hline Shetland Pony & $8.5 \pm 2.9$ & $7.8 \pm 2.8$ & 2 \\
Welsh Pony & $14 \pm 3.7$ & $7.5 \pm 2.7$ & 2 \\
Quarter Horse & $13 \pm 3.5$ & $9.0 \pm 3.0$ & 2 \\
Haflinger Horse $^{1}$ & 10 & 8.5 & 1 \\
Other breeds $^{1}$ & $16 \pm 5.0$ & $8.0 \pm 0.6$ & 5 \\
\hline
\end{tabular}

'Other breeds: Warmblood horse $(\mathrm{N}=1)$, Knabstrupper horse $(\mathrm{N}=1)$, Arabian horse $(N=1)$, Andalusian horse $(N=1)$, Criollo horse $(N=1)$

study period. A commercial compounded feed was used as a source of starch. The ingredients of the compounded feed (36 $\%$ starch, $6.8 \%$ sugar) were oats and micronised cereals in the following descending order based on inclusion rate: oats, wheat, maize, barley, and wheat feed. The test meal was fed at $0730 \mathrm{~h}$ following a $12 \mathrm{~h}$ overnight fast. At $0700 \mathrm{~h}$, an indwelling catheter $(1.8 \times 2.35 \mathrm{~mm} / 12 \mathrm{G}$, Braun, Melsungen, Germany) was inserted into the jugular vein. The catheter was connected to a $50 \mathrm{~cm}$ extension set (Vygon, Aachen, Germany) and sutured in place. The extension set and catheter were flushed with physiological saline after every blood sampling. Blood samples were collected 30 min before feeding the test meal, and thereafter at 30 min intervals for $5 \mathrm{~h}$, and then at 60 min intervals for the following 2 hours. Blood was placed in tubes containing lithium-heparin (15 I.E. Heparin/ml blood, Sarstedt, Nümbrecht, Germany). Blood samples were centrifuged at $2012 \mathrm{~g}$ for $10 \mathrm{~min}$ within $5 \mathrm{~min}$ of collection. Plasma was stored at $-20^{\circ} \mathrm{C}$ until analysed.
Table 3 Breed, age, BCS and number of animals which were included in the verum group

Rasse, Alter und Anzahl der Tiere, die der Verumgruppe zugeordnet wurden

\begin{tabular}{lccl}
\hline Breed & Age & BCS & N \\
\hline Shetland Pony & $11.0 \pm 3.3$ & $7.3 \pm 2.7$ & 2 \\
Welsh Pony & $14.8 \pm 3.9$ & $7.2 \pm 2.7$ & 5 \\
Quarter Horse & 13 & 7.5 & 1 \\
Haflinger Horse $^{\prime}$ & $18.0 \pm 4.2$ & $7.5 \pm 2.7$ & 2 \\
Other breeds $^{1}$ & $16.3 \pm 4.7$ & $7.5 \pm 0.8$ & 5 \\
\hline
\end{tabular}

'Other breeds: Warmblood horse ( $N=2)$, Fiord horse $(N=2)$, Lipizzaner horse $(\mathrm{N}=1)$

\section{Analysis}

Animals were weighed before and after the study using a mobile scale (Firma Tru Test MP Series 600, scaling range 0.5 $1,500 \mathrm{~kg}$ ). Plasma glucose concentrations were determined by glucose oxidase assay (Unimate 7 GLUC GDH, Roche Diagnostics $\mathrm{GmbH}$, Mannheim, Germany) and plasma insulin was determined by radioimmunoassay (Insulin RIA, Coat-A-Count [125I], Siemens Healthcare Diagnostics, Eschborn, Germany).

\section{Statistical methods}

The results are presented as means \pm SD. Incremental area under the plasma glucose and plasma insulin curve (AUC) was calculated using simple non-overlapping polygons, and the area over the baseline without consideration of the area beneath the curve. 
Table 4 Mean plasma glucose $(\mathrm{mmol} / \mathrm{L})$ and mean plasma insulin $(\mu \mathrm{U} / \mathrm{mL})$ concentrations before and after experimental period for the placebo and verum group

Mittlere Plasma Glucosekonzentrationen (mmol/l) und mittlere Plasma Insulinkonzentrationen $(\mu \mathrm{U} / \mathrm{ml})$ im Verlaufe der Beobachtungsperiode für die Placebo- und Verumgruppe

\begin{tabular}{|c|c|c|c|c|c|c|c|c|}
\hline \multirow{3}{*}{$\begin{array}{l}\text { Parameter } \\
\text { Glucose }\end{array}$} & \multirow{3}{*}{$\begin{array}{l}\text { Treatments } \\
\text { Placebo }\end{array}$} & \multirow{3}{*}{$\frac{N}{12}$} & \multicolumn{6}{|c|}{ Experimental period } \\
\hline & & & \multicolumn{3}{|c|}{ Before } & \multicolumn{3}{|c|}{ After } \\
\hline & & & 5.53 & \pm & 0.91 & 5.56 & \pm & 0.46 \\
\hline & Verum & 15 & 6.25 & \pm & 2.08 & 5.96 & \pm & 2.01 \\
\hline \multirow{2}{*}{ Insulin } & Placebo & 12 & 42.9 & \pm & 47.8 & 14.4 & \pm & 8.3 \\
\hline & Verum & 15 & 63.7 & + & 81.9 & 33.2 & + & 35.7 \\
\hline
\end{tabular}

Table 5 Mean peak plasma glucose ( \pm SD, mmol/L) and mean AUC ( \pm SD, mmol x min/L) before (STT 1) and after experimental period (STT 2) for the placebo and verum group

Mittlere Plasma Glucosepeaks ( \pm SD, mmol/l) und mittlere AUC ( $\pm S D, \mathrm{mmol} \times \mathrm{min} / \mathrm{l})$ vor (SST 1) und nach der Supplementierungsphase (STT 2) für die Placebo- und Verumgabe

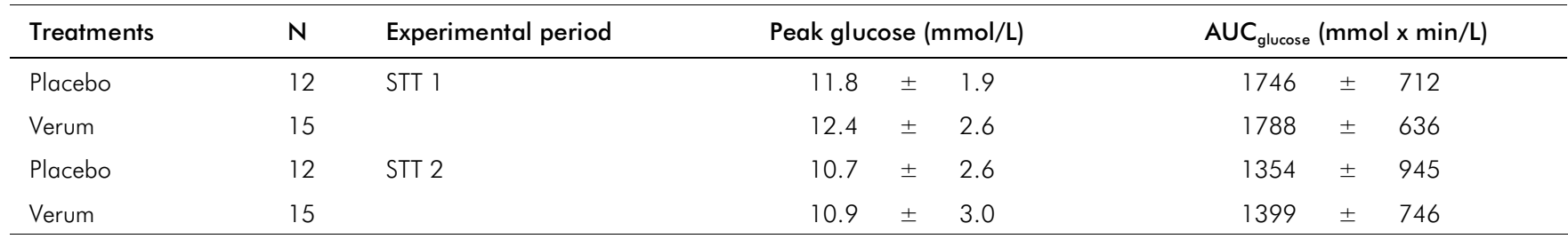

Table 6 Mean peak plasma insulin $( \pm \mathrm{SD}, \mu \mathrm{U} / \mathrm{mL})$ and $\mathrm{AUC}( \pm \mathrm{SD}, \mu \mathrm{U} \times \mathrm{min} / \mathrm{mL})$ before (STT 1) and after experimental period (STT 2) for the placebo and verum group

Mittlere Plasma Insulinpeaks ( $\pm S D, \mu \mathrm{U} / \mathrm{ml}$ ) und mittlere AUC ( $\pm \mathrm{SD}, \mu \mathrm{U} \times \mathrm{min} / \mathrm{ml}$ ) vor (SST 1) und nach der Supplementierungsphase (STT 2) für die Placebo- und Verumgabe

\begin{tabular}{|c|c|c|c|c|c|c|c|c|}
\hline \multirow{2}{*}{$\begin{array}{l}\text { Treatments } \\
\text { Placebo }\end{array}$} & \multirow{2}{*}{$\frac{N}{12}$} & \multirow{2}{*}{$\begin{array}{l}\text { Experimental period } \\
\text { STT } 1\end{array}$} & \multicolumn{3}{|c|}{ Peak insulin $(\mu \mathrm{U} / \mathrm{mL})$} & \multicolumn{3}{|c|}{$A \cup C_{\text {insulin }}(\mu \cup \times \mathrm{min} / \mathrm{mL})$} \\
\hline & & & 1158 & \pm & $753^{\circ}$ & 281541 & \pm & $189698^{a}$ \\
\hline Verum & 15 & & 1901 & \pm & $1443^{b}$ & 492670 & \pm & $358231^{b}$ \\
\hline Placebo & 12 & STT 2 & 883 & \pm & $725^{a}$ & 220986 & \pm & $193617^{a}$ \\
\hline Verum & 15 & & 1277 & \pm & $855^{\circ}$ & 318892 & \pm & $224850^{a}$ \\
\hline
\end{tabular}

Means in the same column with different superscripts are significantly different $(P<0.05)$

Data were subjected to an analysis of variance (ANOVA) for repeated measures (Statistika, StatSoft), factoring the effects of supplementation and time postprandially. When F-values were significant, further analysis was made using the least sig-
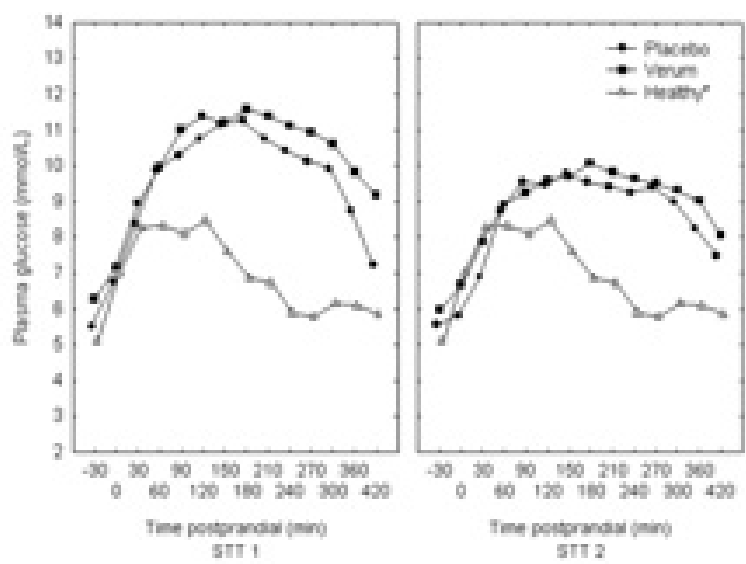

Fig. 1 Mean plasma glucose ( $\mathrm{mmol} / \mathrm{L})$ before (STT 1) and after experimental period (STT 2) for the placebo and Cr group. *Data for healthy horses are adapted from Vervuert et al. (2009)

Mittlere Plasma Glucosekonzentrationen (mmol/l) vor (SST 1) und nach der Supplementierungsphase (STT 2) für die Placebo- oder Chromgabe. Daten der gesunden Pferde sind von Vervuert et al. (2009) entnommen worden nificance difference test. A t-test for unpaired samples was used to analyse the AUC for plasma glucose and plasma insulin, peak plasma glucose and peak plasma insulin. Multiple regression was performed to test the relationship bet-
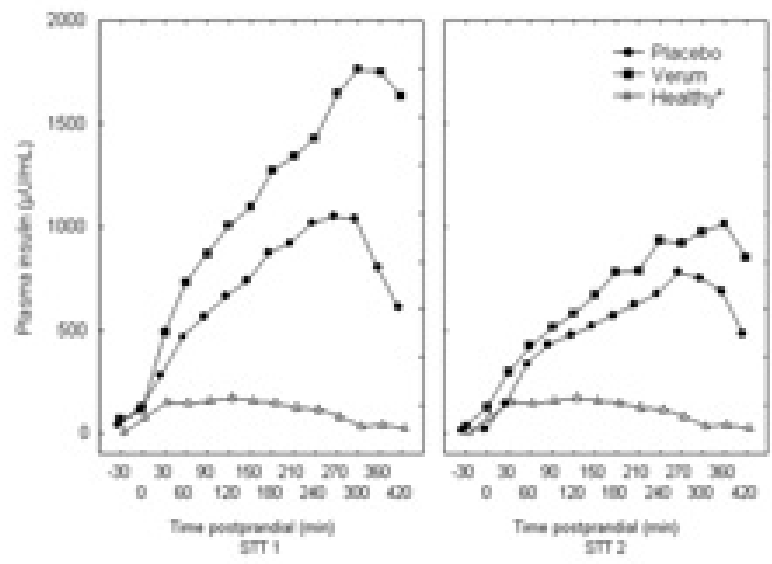

Fig. 2 Mean plasma insulin $(\mu \mathrm{U} / \mathrm{mL})$ before (STT 1) and after experimental period (STT 2) for the placebo and $\mathrm{Cr}$ group. *Data for healthy horses are adapted from Vervuert et al. (2009)

Mittlere Plasma Insulinkonzentrationen $(\mu \mathrm{U} / \mathrm{ml})$ vor (SST 1) und nach der Supplementierungsphase (STT 2) für die Placebo- oder Chromgabe. Daten der gesunden Pferde sind von Vervuert et al. (2009) entnommen worden 
ween body mass, BCS, plasma glucose and plasma insulin. Statistical significance was accepted at $\mathrm{P}<0.05$.

\section{Results}

During the experimental period, horses lost BW in the range of $3.8 \pm 4.3 \%$ for the verum group and $2.1 \pm 3.2 \%$ for the placebo group (treatment $\mathrm{P}>0.05$ ). After $12 \mathrm{~h}$ feed restriction, baseline plasma glucose and plasma insulin concentrations were similar for the different treatment groups before and after supplementation (Table 4) although numerically lower plasma insulin concentrations were measured for both groups after the supplementation period.

A significant increase in plasma glucose was measured 30-60 min after starch intake for both groups before (STT 1) and after the study period (STT 2, Figure 1). In both groups, the plasma glucose levels did not return to basal levels in STT 1 and STT 2. Mean peak plasma glucose values and mean AUC were similar for both groups without any significant differences before (STT 1) and after the study period (STT 2, Table 4).

A significant rise in plasma insulin was measured 30 min after starch intake in every case; a return to resting levels did not occur during the sampling phase (Figure 2). For STT 1, mean peak plasma insulin levels and AUC were significantly higher for the verum group than for the placebo group $(P<0.05$, Table 4, Figure 2), and a significant decrease in peak plasma insulin and AUC was observed after the end of the experimental period (STT 2) following feeding the $\mathrm{Cr}$-enriched yeast $(\mathrm{P}<0.05)$, whereas the decrease in mean peak insulin and AUC was less pronounced for the horses given the placebo (time $\mathrm{P}>0.05$, Table 5, Figure 2).

\section{Discussion}

At the beginning of the study, mean resting insulin levels after feed restriction exceeded $20 \mu \mathrm{U} / \mathrm{mL}$ which provides evidence of IR (ACVIM Consensus Statement 2009). Additionally, the high mean body condition score of the ponies and horses indicated regional or general adiposity, a main risk factor for IR (van Weyenberg et al. 2008, Carter et al. 2009). In contrast, mean resting plasma glucose concentrations were still in the physiological range, suggesting that measurement of resting plasma glucose has limited diagnostic value in identifying cases of IR.

As expected, starch intake increased postprandial plasma glucose and plasma insulin responses of the animals. In healthy horses, postprandial glycaemic and insulinaemic responses to an identical amount of starch were less pronounced (Vervuert et al. 2009) than the responses measured with insulin-resistant animals, suggesting a dysregulation in glucose metabolism. In our study we did not perform dynamic testing for insulin resistance like combined insulin-glucose tolerance test which monitors the glycaemic response to a combination of exogenous glucose and insulin. Although a high glycaemic and insulinaemic response strongly suggests IR, this procedure has not fully validated as tests for insulin resistance in ponies and horses (Durham et al. 2010).

However, a more blunted postprandial insulinaemic response was observed for both groups during STT 2, but with a more pronounced reduction in insulin profile when $\mathrm{Cr}$-enriched yeast was fed. Feeding $\mathrm{Cr}$ to diabetic humans has become quite popular as it has been shown to improve insulin sensitivity (Lukaski 1999, Cefalu et al. 2002). It has been suggested that $\mathrm{Cr}$ decreases insulin levels and improves glucose disposal in Type 2 diabetic and obese humans. In this context it has been hypothesized that $\mathrm{Cr}$ forms a complex between insulin and insulin receptors that facilitates the insulin-tissue interaction (Mertz 1993). The proposed mode of action of $\mathrm{Cr}$ is that increases in blood insulin levels stimulate its uptake by insulin-dependent cells, resulting in the binding of $\mathrm{Cr}$ to chromodulin. The binding of four $\mathrm{Cr}$ ions to chromodulin enables the link to the insulin-stimulated insulin receptor, and hereby amplifies insulin signalling (Davis et al. 1996, Vincent 2000). In the present study, Cr supplementation seemed to improve insulin signalling as postprandial insulin responses were significant lower during STT 2 for the Cr-treated animals. However, it must be emphasized that the animals were still suffering by impaired glucose regulation as indicated by supraphysiological glucose and insulin responses to starch intake when compared to healthy horses (Vervuert et al. 2009).

In the present study, we used a $\mathrm{Cr}$ dosage which was adapted from human treatments; a higher dosage might have greater potential. There are no specific $\mathrm{Cr}$ requirements stated for equids. It is supposed that $\mathrm{Cr}$ absorption from a typical equine diet, including feedstuffs like hay or grains, is $<$ $0.5 \%$, whereas $\mathrm{Cr}$ absorption from an organic source like a Cr-enriched yeast exceeded 25\% (McDowell 2003). Further studies are required to obtain more information on $\mathrm{Cr}$ metabolism and to establish recommendations for $\mathrm{Cr}$ intake by the horse.

We are aware that the postprandial insulin responses were significant higher at the beginning of the study in the group to be fed $\mathrm{Cr}$ when compared to the placebo group. In consequence, it cannot be excluded that the differences in baseline assessment might have affected the outcome of this study. However, this confounding factor should be addressed in future studies as the great variation in insulin concentrations has also been reported by others (e.g. Freestone et al. 1992) and possibly mirrors different levels/degrees of IR which needs further elucidation.

It was interesting to note that the placebo horses had non-significant changes in resting and postprandial insulin profiles which were presumably linked to body weight loss. Van Weyenberg et al. (2008) observed an improvement in insulin sensitivity in ponies losing up to $18 \%$ of their initial body weight by energy restriction. Freestone et al. (1992) improved insulin sensitivity in obese ponies by limit feeding (diet not defined) for a four week period resulting in weight losses of $\sim 3 \%$ of BW. A similar scale of body weight loss resulted in our study following hay restriction (most animals previously had access to hay ad libitum) and a low-intensity exercise programme. Diet-induced weight gain in horses resulted in decreased insulin sensitivity that was effectively compensated by an increase in insulin secretory response (Carter et al. 2009).

Adipose tissue is recognized as the largest endocrine organ in the body, secreting so-called adipokines that play a major 
role in the regulation of immune, metabolic and vascular physiology (Hutley and Prins 2005). Adipokines include leptin, adiponectin, tumor necrosis factor alpha, several interleukins (e.g. IL-6) and plasminogen activator-inhibitor-1. The secretion of proinflammatory adipokines are supposed to decrease insulin sensitivity, induce oxidative stress and impair microvascular function. A significant reduction in serum levels of tumor necrosis factor alpha protein was measured following weight loss in horses (Adams et al. 2009). In consequence weight loss seemed to modify IR by blunting inflammatory responses via adipose tissue.

In conclusion, data from the literature and from the current study showed that body weight loss moderates IR. A longer experimental period with continuing weight loss would probably further affect insulin sensitivity as previously suggested by von Weyenberg et al. (2008). In addition, Cr supplementation ( $25 \mu \mathrm{g} \mathrm{Cr} / \mathrm{kg} \mathrm{BW}$, provided by a $\mathrm{Cr}$-enriched yeast) seemed to have some potential in the treatment of IR in equids. Further studies are necessary to obtain more detailed information on $\mathrm{Cr}$ metabolism, suitable dosage and duration/frequency of treatment. $\mathrm{Cr}$ supplementation alone is an inadequate therapy and should always be associated with body weight loss due to restriction of energy intake and moderate exercise, key factors in the treatment of EMS.

\section{References}

Adams A. A., Katepalli M. P., Kohler K., Reedy S. E., Stilz J. P., Vick M. M., Fitzgerald B. P., Lawrence L. M. and Horohov D. W. (2009) Effect of body condition, body weight and adiposity on inflammatory cytokine responses in old horses. Vet. Immunol. Immunopathol. 127, 286-294

Anke M., Dorn W. und Jaritz M. (2005): Chrom in der Ernährungskette von Pflanze, Tier und Mensch. Rekasan J. 12, 59-73

Asplin K. E., Sillence M. N., Pollitt C. C. and McGowan C. M. (2007) Induction of laminitis by prolonged hyperinsulinaemia in clinically normal ponies. Vet. J. 174, 530-535

Bartlett H. E. and Eperiesi F. (2008) Nutritional supplementation for type 2 diabetes: a systematic review. Ophthalmic Physiol. Opt. 28, 503-523

Carter R. A., McCutcheon L. J., George L. A., Smith T. L., Frank N. and Geor R. J. (2009) Effects of diet-induced weight gain on insulin sensitivity and plasma hormone and lipid concentrations in horses. Am. J. Vet. Res. 70, 1250-1258

Cartmill J. A., Thompson D. L., Storer W. A., Huff N. K. and Waller C. A. (2005) Effects of chromium supplementation on plasma insulin and leptin in horses with elevated concentrations of leptin. In: Proc. Equine Sci. Soc. Arizona, 352

Cefalu W. T., Wang Z. Q., Zhang X. H., Baldor L. C. and Russell J. C. (2002) Oral chromium picolinate improves carbohydrate and lipid metabolism and enhances skeletal muscle Glut-4 translocation in obese, hyperinsulinemic (JCR-LA corpulent) rats. J. Nutr. 132, 1107-1114

Davis C. M., Sumrall K. H. and Vincent J. B. (1996) A biologically active form of chromium may activate a membrane phosphotyrosine phosphatase (PTP). Biochemistry 35, 12963-12999

Frank N., Geor R. J., Bailey S. R., Durham A. E. and Johnson P. J. (2009) ACVIM Consensus Statement: Equine Metabolic Syndrome, unpublished
Freestone J. F., Beadle R., Shoemaker K., Bessin R. T., Wolfsheimer K. J. and Church C. (1992) Improved insulin sensitivity in hyperinsulinaemic ponies through physical conditioning and controlled feed intake. Equine Vet. J. 24, 187-190

Gentry L. R., Thompson D. L., Fernandez J. M., Smith L. A., Horohov D. W. and Leise B. S. (1999) Effects of chromium tripicolinate supplementation on plasma hormone and metabolite concentrations and immune function in adult mares. J. Equine Vet. Sci. 19, 259-265

Henneke D. R., Potter G. D., Kreider J. L. and Yeates B. F. (1983) Relationship between condition score, physical measurements and body fat percentage in mares. Equine Vet. J. 15, 371-372

Hutley L. and Prins J. B. (2005) Fat as an endocrine organ: relationship to the metabolic syndrome. Am. J. Med. Sci. 330, 280-289

Johnson P. J. (2002) The equine metabolic syndrome peripheral Cushing's syndrome. Vet. Clin. North Am. Equine Pract. 18, 271-293

Kashyap S.R., Defronzo R.A. (2007): The insulin resistance syndrome: physiological considerations. Diab. Vasc. Dis. Res. 4, 13-19

Lukaski H. C. (1999) Chromium as a supplement. Annu. Rev. Nutr. 19, 279-302

McDowell L. R. (2003) Minerals in Animal and Human Nutrition. Elsevier Science, Amsterdam pp. 497-504

Mertz W. (1993) Chromium in human nutrition: a review. Nutr. 123, 626-633

Mordini A., Piva A. and Piva G. (1997) The European perspective on organic chromium in animal nutrition. In: Proc. of Alltech s 13th Annual Symp. Nottingham, UK, University of Nottingham Press, pp. $227-240$

OHE. A. and Kivipelto J. (1999): Influence of chromium tripicolinate on growth and glucose metabolism in yearling horses. J. Anim. Sci 77, 3022-3030

Pagan J. D., Rotmensen T. and Jackson S. G. (1995): The effect of chromium supplementation on metabolic response to exercise in Thoroughbred horses. In: Proc. Equine Nutr. Symp. California, 96-101

Potenza M. V. and Mechanick J. I. (2009) The metabolic syndrome: definition, global impact, and pathophysiology. Nutr. Clin. Pract. 224, 560-577

Reaven G. M. (1998) Insulin resistance and human disease: a short history. J Basic Clin. Physiol. Pharmacol. 9, 387-406

Van Weyenberg S., Hesta M., Buyse J. and Janssens G.P. (2008): The effect of weight loss by energy restriction on metabolic profile and glucose tolerance in ponies. J. Anim. Physiol. Anim. Nutr. (Berl). 92, 538-545

Vervuert I., Cuddeford D. and Coenen M. (2006) Effects of chromium supplementation on selected metabolic responses in resting and exercising horses. Equine Comp. Exerc. Physiol. 3, 19-27

Vervuert I., Voigt K., Hollands T., Cuddeford D. and Coenen M. (2009) Effect of feeding increasing quantities of starch on glycaemic and insulinaemic responses in healthy horses. Vet. J. 182, 67-72

Vick M. M., Murphy B. A., Sessions D. R., Reedy S. E., Kennedy E. L., Horohov D. W., Cook R. F. and Fitzgerald B. P. (2008) Effects of systemic inflammation on insulin sensitivity in horses and inflammatory cytokine expression in adipose tissue. Am. J. Vet. Res. 69, 130-139

Vincent J. B. (2000) Elucidating a biological role for chromium at a molecular level. Acc. Chem. Res. 33, 503-510

PD Dr. Ingrid Vervuert

Institut für Tierernährung, Ernährungsschäden und Diätetik

Universität Leipzig

Gustav-Kühn-Str. 8

04159 Leipzig

ingrid.vervuert@vetmed.uni-leipzig.de 